\title{
Social Justice in the Post-Affluent Society
}

\author{
Amitai Etzioni ${ }^{1}$
}

Operating under the assumption that the current technological revolution will result in increased unemployment due to smart machines being used in roles traditionally occupied by humans, this article addresses how societal promotion of communitarian pursuits over affluence will lead to increased social justice. A greater reallocation of wealth can be expected when communitarianism thrives because social bonds create a sense of obligation to support less endowed members. Furthermore, even though the shift to a postaffluent society has not yet occurred, millions are already committed to pro-social pursuits and are demonstrating that when people of means embrace social justice, they are willing to share more readily. [Article copies available for a fee from The Transformative Studies Institute. E-mail address: journal@transformativestudies.org Website: http://www.transformativestudies.org (C2017 by The Transformative Studies Institute. All rights reserved.]

KEYWORDS: Affluence, Communitarianism, Social Justice.

The article spells out the reasons and provides evidence in support of the hypothesis that if the culture of a society shifts from one that extols affluence to one that extols communitarian pursuits - major gains for social justice will become much more probable. An obvious reason to expect that this hypothesis will hold true is that the more members of a particular social grouping view each other as members of the same

\footnotetext{
${ }^{1}$ Amitai Etzioni, Ph.D., is a University Professor and Professor of International Relations at The George Washington University. He served as a Senior Advisor at the Carter White House and taught at Columbia University, Harvard Business School, and University of California at Berkeley. A study by Richard Posner ranked him among the top 100 American intellectuals. He is the author of numerous op-eds and his voice is frequently heard in the media. He is the author of many books, including The Active Society, The Moral Dimension, Security First, The New Golden Rule, Hot Spots, and My Brother's Keeper. His most recent book, Privacy in a Cyber Age, was just published by Palgrave MacMillan in 2015. Address correspondence to: Dr. Amitai Etzioni, The George Washington University, 1922 F Street NW, Washington, District of Columbia 20052; e-mail: etzioni@gwu.edu.
} 